Available online at: http://journal.uinsgd.ac.id/index.php/kt

KhazanahTheologia, Vol. 2 No. 1: 1-8

DOI: $10.15575 /$ kt.v2i1.6745

\title{
Kualifikasi Guru berdasarkan 1 Tesalonika 2:7-12
}

\author{
Ezra Tari* \\ Institut Agama Kristen Negeri Kupang, Nusa Tenggara Timur, Indonesia \\ E-mail: tariezra@gmail.com
}

\begin{abstract}
The author studies 1 Thessalonians 2: 7-12 about teacher qualifications. This study departs from the writer's anxiety about the condition of the teacher. Where teachers are currently required to perform tasks according to the educational qualifications of each level. But in reality, there are still many teachers who have not met the minimum bachelor requirements. One obstacle is the distance to go to college and the age that is not young anymore. As a result, many teachers have difficulty in accessing education. With that problem, the author examines the qualifications of teachers based on 1 Thessalonians 2: 7-12.The method used by the author is qualitative. The method used to trace the actual state of the object of research. The study used is exegese. Exegese tries to understand the text from various aspects. Based on the study conducted by the author in this paper, there are two important things that need to be learned, namely hospitality in love. And the example of struggle is an example for many people. Teaching is a very important task in Paul's ministry. Paul gave an example of how to work hard in work as a teacher, providing holistic service. This paper is a teacher qualification study that touches on nature that must be possessed by a teacher.
\end{abstract}

Keywords: Qualifications; Teacher; 1 Thessalonians 2: 7-12.

\begin{abstract}
Abstrak
Penulis melakukan kajian terhadap 1 Tesalonika 2:7-12 tentang kualifikasi guru. Kajian ini berangkat dari kegelisahan penulis terhadap kondisi guru. Di mana guru sekarang ini dituntut menunaikan tugas sesuai kualifikasi pendidikan masing-masing jenjang. Namun pada kenyataannya masihbanyak guru yang belum memenuhi persyaratan minimal sarjana. Salah satu kendala adalah jarak tempuh tempat kuliah dan usia yang tidak muda lagi. Akibatnya, guru banyak mengalami kesulitan dalam mengaksesn pendidikan. Dengan persoalan itu maka, penulis mengupas tentang kualifikasi guru berdasarkan 1 Tesalonika 2:7-12. Metode yang digunakanpenulisadalahkualitatif. Metode yang digunakan untuk menelusuri keadaan yang sebenarnya dari objek penelitian. Kajian yang digunakan adalah eksegese. Ekegese berusaha memahami teks dari berbagai segi. Berdasarkan kajian yang dilakukan oleh penulis dalam tulisan ini, maka ada dua hal penting yang perludipelajari, yakni keramahan dalam kasih. Dan keteladanan dalam perjuangan, menjadi contoh bagi banyak orang. Mengajar merupakan tugas yang amat penting dalam pelayan Paulus. Paulus memberikan contoh bagaimana kerja keras dalam pekerjaan sebagai pengajar, memberikan pelayanan yang holistik Tulisan ini merupakan studi kulifikasi guru yang menyentuh sifat dasar yang harus dimiliki oleh seorang guru.
\end{abstract}

Kata Kunci: Kualifikasi; Guru; 1 Tesalonika 2:7-12.

\section{PENDAHULUAN}

Kualifikasi guru dibagi tiga dimensi yakni kompetensi yang menyangkut: 1) rencana pengajaran (teaching plans and materials), 2) prosedur mengajar (classroom procedurs), dan 3) hubungan antarpribadi (interpersonal skill)(Jahidi, 2017). Kualifikasi Pendidikan guru di Indonesia timur masih rendah, baik kualifikasi akademik maupun kualifikasi non akademik, masih banyak guru yang memiliki kualifikasi di bawah standar (D-4/S-1) dan mengajarkan matapelajaran yang berbeda dengan kualifikasi pendidikannya sehingga mempengaruhi proses pembelajaran. Dalam pengalaman penulis banyak guruguru dari daerah-daerah yang melanjutkan studi untuk memenuhi kualifikasi yang ditetapkan

* Corresponding author 
Khazanah Theologia, Vol. 2 No. 1: 1-8

Kualifikasi Guru berdasarkan 1 Tesalonika 2:7-12

pemerintah. Guru-guru yang melanjutkan studi dari segi umur tidak muda lagi. Sehingga proses pembelajaran dan studi terkesan sekedar formalitas. Pemerintah menerangkan bahwapekerjaan guru adalah tenaga professional sehingga hanya dapat dilakukan oleh seseorang yang mempunyai kualifikasi akademik, kompetensi, sertifikat pendidik sesuai dengan persyaratan untuk setiap jenjang dan jenis pendidikan (Putri, 2019). Berdasarkan data UNESCO dalam Global Education Monitoring (GEM) Report 2016, pendidikan di Indonesia menempatiperingkat ke-10 dari 14 negara berkembang dan kualitas guru menempatiukuran ke-14 dari 14 negara berkembang di dunia. Jumlah guru mengalami peningkatan sebanyak 382\% dari 1999/2000 menjadi sebanyak 3 juta orang lebih, sedangkan peningkatan jumlah peserta didikhanya $17 \%$. Dari 3.9 juta guru yang ada, masih terdapat $25 \%$ guru yang belum memenuhi syarat kualifikasi akademik dan $52 \%$ di antaranya belum memiliki sertifikat profesi. Dengan jumlah guru yang banyak, diharapkan kegiatan belajar yang optimal dapat tercapai. Sayangnya, meningkatnya kuantitas guru tidak sejalan dengankualitasnya (Maura, 2018).

Permendiknas Nomor 16 Tahun 2007: Standar KualifikasiAkademik dan Kompetensi Guru menerangkan bahwa kualifikasi akademik guru melalui pendidikan formal. Kualifikasi akademik guru pada satuanpendidikanjalur formal. Kualifikasiakademikpendidikan minimum diploma empat (D-IV) atausarjana (S1) program studi yang sesuaidenganmatapelajaran yang diajarkan/diampu, dan diperolehdari program studi yang terakreditasi. Kualifikasi akademik guru melalui uji kelayakan dan kesetaraan kualifikasi akademik yang dipersyaratkan untuk dapat diangkat sebagai guru dalam bidangbidang khusus yang sangat diperlukan tetapi belum dikembangkan di perguruan tinggi dapat diperoleh melalui uji kelayakan dan kesetaraan (Umasuhi, 2014). Ada empat penyebab rendahnya kualitas guru. Pertama, ketidaksesuaian disiplin ilmu dengan bidang ajar. Kemungkinan masih ada guru di sekolah yang mengajar mata pelajaran tidak bidang studi yang dipelajarinya. Hal ini terjadi karena kurangnya guru pada bidang studi tertentu. Kedua, kualifikasi guru yang belum setara sarjana. Konsekuensinya, standar keilmuan yang dimiliki guru menjadi tidak memadai untuk mengajarkan bidang studi yang menjadi tugasnya. Keempat, rekrutmen guru yang tidak efektif. Karena masih banyak calon guru yang direkrut tidak melalui mekanisme yang profesional, tidak mengikuti system rekrutmen yang dipersyaratkan (Yunus, 2017). Solusi berdasarkanpenelitian Marten Masoka, Ibrohim, dan Sri Endah Indriwati menawarkan untuk mencegah dan mengatasi permasalahan guru sains terkait dengan kualifikasi yaitu studi lanjut bagi guru usia produktif kejenjang yang lebih tinggi, memberikan beasiswa kepada putra-putri daerah untuk mengenyam pendidikan kejenjang yang lebih tinggi, sedangkan solusi terkait dengan permasalahan kompetensi, antara lain dengan melakukan pembinaan profesional, dan program profesi guru (Masoka et al., 2017).

Fieka Nurul Arifa dan Ujianto Singgi Prayitno mengungkapkan bahwa Pendidikan Profesi Guru (PPG) merupakan solusi jangkapanjang dari keresahan terhadap lemahnya kualitas guru saat ini. Melalui PPG guru yang pension nantinya dapat digantikan oleh guru yang telah memiliki kualifikasi dan kompetensi standar sesuai dengan Standar Nasional Pendidikan (SNP). Begitu pula dalam pemenuhan guru baik dipusat maupun di daerah mengingat pertumbuhan jumlah sekolah juga terus meningkat (Arifa \& Prayitno, 2019). Kualifikasi akademik yang sesuai menjadi modal utama seorang guru dalam melaksanakan tugasnya. Tidakakan berjalan maksimal misalnya, seorang pendidik yang kualifikasi akademiknya bahasa, kemudian mengajar matematika. Begitu juga guru yang kualifikasinya non pendidikan kemudian mengajar bidang pendidikan. Selain guru mengalami kesulitan dalam proses pembelajaran, siswa juga tidak memperoleh pengetahuansesuaidengantujuan pembelajaran. Karena kualifikasi akademik yang tidak sesuai, kompetensi akademik juga tidak sesuai (Salamah, 2019). Hasil survei yang dilakukan Persatuan Guru Republik Indonesia (PGRI) mengenai dampak sertifikasi profesi guru terhadap kinerja guru. Denganmelakukansurvey terhadap 16 dari 28 provinsi yang diteliti. Hasilnya sudah menunjukkan jika kinerja guru yang sudah disertifikasi belum meningkat secara signifikan. Guru-guru yang sudah lolos sertifikasi umumnya tidak menunjukkan kemajuan, baik dari sisi pedagogis, kepribadian, profesional, maupun sosial. Guru hanya aktif menjelang sertifikasi, tetapi setelah dinyatakan lolos, kualitas mereka justru semakin menurun (Fauzi, 2019). Maka untuk menjadi seorang guru yang berkualitas dan produktif itu tidaklah mudah. Apalagi bila tidak didukung oleh kondisi yang kondusif (tingkat kesejahteraan yang memadai dan mekanisme kontrol proses pendidikan yang efektif). Oleh karena itu guru seyogyanya memiliki perilaku kemampuan yang memadai untuk 
Khazanah Theologia, Vol. 2 No. 1: 1-8

Kualifikasi Guru berdasarkan 1 Tesalonika 2:7-12

mengembangkan siswanya secara utuh. Untuk melaksanakan tugasnya secara baik sesuai dengan profesinya, guru perlu menguasai berbagai hal kompetensi yang dimiliki (Mukti, 2017).

Berdasarkan sejumlah pemikiran yang telah penulis paparkan di atas maka fokus penelitian adalah untuk mengupas kualifikasi guru berdasarkan 1 Tesalonika 2:7-12. Penyelidikan dan penekanan penulis tentang kualifikasi guru yakni keramahan, keteladanan dalam kasih, perjuangan dan keluarga yang akan ditelusuri dalam pembahasan. Sehingga perspektif tentang kualifikasi guru didapatkan secara komprehensif.

\section{METODE PENELITIAN}

Penulis dalam memaparkan penelitian menggunakan metode kualitatif. Sugiyono dalam buku metode penelitian manajemen, mengatakan bahwa metode penelitian kualitatif adalah dapat diartikan sebagai metode penelitian yang digunakanuntuk meneliti kondisiobjek yang alamiah(Sugiyono, 2013). Salah satu model kualitatif dalam membedah isi Alkitab adalah metode eksposisi. Dalam mengeks posisi dibutuhkan exegese. Exegese adalah mengutamakan penyelidikan teks bahasa penulis sesuai dengan bahasa aslinya dan bagaimana teks itu relevan untuk situasi sekarang. Dan penulis berusaha memahami maksud penulis sesuai dengan konteksaslinya (Yusuf, 2019). Salah satu bagian dari exegesea dalah eksposisi. Marulak Pasaribu menyimpulkan tujuan eksposisi adalah membentangkan maksud dan tujuan penulisan kitab. Beberapa prinsip yang digunakan untuk mengeksposisi Injil Sinoptik yaitu: pertama: menyelidiki bahasa yang dipakai. Kedua: mengenal jenis kesusasteraan (genre) yang dibaca. Ketiga: mempelajari latar belakang budaya, sosial dan sejarah penulisan kitab(Pasaribu, 2005).

\section{HASIL DAN PEMBAHASAN}

Bacaan 1 Tesalonika 2:7, Paulus dan kerabat kerjanya menunjukkan suatu teladan sikap rohani yang harus dimiliki semua misionaris, penginjil, dan gembala ketika memberitakan Injil. 1) Sebagai misionaris, mereka mempunyai sikap ibu yang lemah lembut dan memelihara; dengan pengorbanan besar mereka berusaha khusus untuk mengasuh, melindungi, dan memenuhi keperluan rohani orangorang yang baru percaya ini. 2) Kelembutan menunjukkan bahwa mereka tidak bertindak sebagai orang yang sangat penting. 3) Para misionaris ini memiliki kerinduan dan kasih yang begitu besar bagi orang Tesalonika sehingga mereka rela membagi hidup mereka dengan jemaat itu (1Tes 2:8). 4) Mereka mengabdikan banyak waktu, bahkan sampai kelelahan, supaya dapat memberitakan Injil (1Tes 2:9). 5) Mereka hidup kudus dan tak bercacat di hadapan jemaat itu, sambil menasihati dan menguatkan hati mereka seperti seorang bapa (1Tes 2:10-12). Nas : 1 Tesalonika 2:10, Paulus tidak menerima pandangan yang keliru tentang "kekristenan yang berdosa", yang menyatakan bahwa keselamatan yang disediakan oleh Kristus dan penebusan oleh darah-Nya tidak cukup untuk menyelamatkan manusia dari perhambaan dan kuasa dosa. Ajaran yang tidak alkitabiah ini menyatakan bahwa setiap hari semua orang Kristen akan berbuat dosa melawan Allah dalam ucapan, pikiran, dan perbuatan sepanjang hidup di dunia ini (Sabda, 2019).

Kualifikasi yang ditawarkandalam 1 Tesalonika 2:7-12, penulis memaparkan sebagai berikut:

\section{Keramahan}

Kualifikasi guru yang harus dimiliki adalah berlaku ramah, sama seperti seorang ibu mengasuh dan merawatianaknya. Paulus menyampaikan kepada jemaat Tesalonika bahwa tetapi kami berlaku ramah di antara kamu, sama seperti seorang ibu mengasuh dan merawati anaknya (ay.7). Dalam bahasa Indonesia sehari-hari, tetapi kami bersikap lemah lembut sewaktu berada di tengah-tengah kalian, seperti seorangibu, kami bersikap lemah lembut sewaktu berada di tengah-tengah kalian, seperti seorangibu: beberapa naskah kuno: kami seperti anak-anak sewaktu berada di tengah-tengah kalian; kami seperti seorang ibu merawat anak-anaknya. Ibu diterjemahkan dari bahasa Yunani berarti wanita yang menyusui bayi. Dapat juga berarti wanita yang menyusui bayi orang lain. Dalam konteks ini, berkaitan dengan kasih sayang dan baik hati (Ellingworth, 2019). Kata mengasuh mencakup merawat, member makan, menunjukkanperhatian yang lembut daripada sekadar merawat. Pemikiran sebagai ibu yang mengasuh sangat berbeda dengan pemikiran kehormatan atau kedudukan(Nee \& Lee, 2020). 
Khazanah Theologia, Vol. 2 No. 1: 1-8

Kualifikasi Guru berdasarkan 1 Tesalonika 2:7-12

Paulus menggunakan gambaran mengenai orang tua yakni pertama, ia melukiskan dirinya sendiri dan rekan-rekannya sebagai seorang ibu dengan lemah lembut mengasuh anak-anaknya. Kedua ia melukiskan ketiga sifat kerasulannya, ketika menasehati jemaat dengan cara seorang ayah memberi perhatian terhadap masing-masing anaknya (Bergant, 2015). Pasal 2:7: kami berlaku ramah di antara kamu. Ada suatu variasi naskah Yunani di antara penggunaan istilah (1)"bayi" (nēpios) dan (2) "lembut" (épios). Atas dasar kenaskahan yang murni nomor 1 adalah yang terbaik; atas dasar kontekstual. Nomor 2 tampaknya adalah yang terbaik (yang mungkin mencerminkan perubahan penulisan yang disengaja). Origenes dan Agustinus percaya Paulus berbicara kepada jemaat Tesalonika dalam bahasa bayi sehingga mereka bias mengerti. Paulus menggunakan bahasa orang tua dalam ay. 7, 8 dan 11. Dia melihat dirinya sebagai orang tua rohani mereka (Utley, 2019). Paulus dalam bagian ini mengingatkan kembali kepada para pembaca suratnya bahwa para pemberita Injil adalah seorang rasul, sehingga hal yang ditekankan olehnya adalah masalah tanggung jawab. Ia lebih menekankan hal tersebut dari pada menekankan tentang hak istimewa yang dimiliki oleh para pemberita Inji litu(Rumahlatu, 2019).

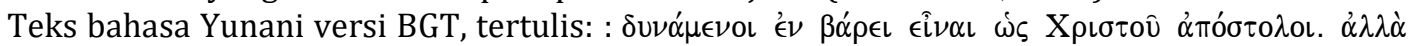

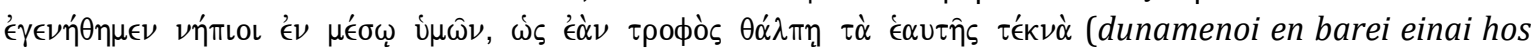
Kristu apostoloi. Alla egenethen nepioi en menoi humon ean tropos talpe ta eautes tekna). Dalam ayat ini

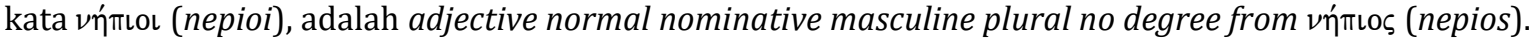
Diterjemahkan infant, minor,1.lit. of very young children: child (Mat. 21:16; 1 Kor. 13:11 (five times). Fig. immature Rm. 2:20; 1 Kor. 3:1; Ef. 4:14; Ibr. 5:13). Childlike, innocent (Mat 11:25; Luk 10:21. 2.minor, not yet of age (Ga.l 4:1, 3; 1 Tes. 2:7) (Bibleworks, 2006). Sama seperti seorang ibu mengasuh dan merawati anaknya. Ini adalah sebuah kalimat third classconditional. Kata kerjanya secarah arfiah berarti "menghangatkan" dan umumnya digunakan untuk induk burung "menghangatkan" anak-anak mereka (lih. Ef 5:29). Ini adalah metafora untuk menyusui. Paulus (lih. Gal. 4:19), seperti Yesus (lih. Mat 23:37), menjelaskan kasih-Nya kepada mereka dalam istilah feminin (lih. Kel 19:4; Yes 66:13; Hos 11:4; dan Kej 1:2)(Utley, 2010).

Kata tpoфòs (torpos), noun nominative feminine singular common. Diterjemahkan nurse, possibly mother. $\theta \alpha \dot{\lambda} \lambda \Pi \eta$ (talpe), verb subjunctive present active 3rd person singular from $\theta \alpha \dot{\alpha} \pi \omega$ (talpo). Diterjemahkan cherish, comfort (Ef. 5:29; 1 Th 2:7) (Bibleworks, 2006). Sebuah kontras yang tajam. Ramah (epioi). Banyak naskah yang bagusmemakai kata bayi (nepioi), yang maksudnya bahwa Paulus, sama sekali tidak menyombongkan diri, sebetulnya menjadi seperti seorang anak yang memakai bahasa bayi untuk berkomunikasi dengan jemaat yang baru berdiri itu. Nas manapun yang dipilih, Paulus, bukannya menjadi beban, malah justru turun tangan untuk membantu. Ibu yang mengasuh dan merawat anaknya. Paulus memelihara hubungan ganda dengan orang-orang yang ia menangkan: di hadapan Allah ia dan mereka adalah saudara seiman (1:4; $2: 1$.); sekalipun demikian mereka adalahanakanaknya (bdg. 2:11) yang telah dibawanya memasuki hidupberiman dan yang untuk pemeliharaan mereka ia bertanggungjawab (Wycliffe, 2019). Kata (homeiromai) tidak muncul di tempat lain di seluruh Perjanjian Baru. Ini digunakan dalam Septuaginta dalam Ayub 3:21. Dalam literatur Yunani ini adalah istilah kasih sayang yang kuat yang terkait dengan kerinduan orang tua kepada anak-anak mereka yang mati (Utley, 2010).

Paulus menunjukkan sikap yang lemah lembut, walaupun bias saja ia bertindak dengan wewenang seorang rasul Kristus. Perilaku seperti itu sangat memberi nama baik bagi agama, dan paling sesuai dengan cara Allah yang penuh kasih karunia dalam berurusan dengan orang-orang berdosa, di dalam dan melalui Injil. Rasul besar ini, walaupun dia membenci dan menghindari sanjungan, sangat merendahkan dirinya kepada semua orang. Dia menyesuaikan dirinya dengan kemampuan setiap orang, dan telah menjadi segala-galanya bagi semua orang. Dia menunjukkan kebaikan dan perhatian seperti seorang ibu yang merawat anak-anaknya dengan penuh kasih sayang. Ini adalah cara untuk memenangkan orang banyak, yang lebih baik dari pada memerintah dengan keras. Firman Allah sungguh penuh kuasa. Firman itu sering datang disertai kekuasaan yang dahsyat terhadap pikiran manusia, dan selalu sanggup untuk menginsafkan dengan penilaian yang adil. Namun, Firman itu juga disertai dengan kuasa yang menyenangkan hati, ketika pelayan-pelayan Injil berperilaku sedemikian rupa sehingga dikasihi orang banyak. Dan ia seperti seorang ibu yang merawat anaknya, dengan bersabar terhadap sikap anak yang suka melawan, dan merendahkan diri untuk tugas-tugas rendah 
Khazanah Theologia, Vol. 2 No. 1: 1-8

Kualifikasi Guru berdasarkan 1 Tesalonika 2:7-12

Ezra Tari

demi kebaikannya, menyusui dan merawat anak itu di dadanya. Demikian pula, dengan cara yang sama pelayan-pelayan Kristus harus bersikap terhadap jemaat mereka (Henry, 2019).

\section{Keteladanan dalam Kasih}

Terjemahan dalam bahasa Indonesia sehari-hari ayat 8; karena kasih sayang kami, kami bersedia memberikan kepadamu bukan saja Kabar Baik yang dari Allah itu, tetapi hidup kami pun juga. Sebab kami sangat mengasihi kalian. Ini menunjukkan kemahalan dari pelayanan serta kasih dari Rasul ini. Pelayanan bukanlah sesuatu yang dilakukan, melainkan adalah siapa manusia (Utley, 2010). Dalam bahasa tertentu, ungkapan demikianlah kami, dalam kasih sayang yang besar akan kamu, lebih tepat kalau diterjemahkan menjadi karena kasih sangat mengasihi kalian. Istilah yang digunakan untuk menerjemahkan kasih sayang harus mencakup semua unsur yang mengungkapkan persahabatan dan persekutuan(Ellingworth, 2019).

Kasih sayang yang besar. Kata yang hanya dipakai di sini saja dalam Perjanjian Baru, berarti rasa kasih sayang dan kerinduan yang hangat. Para rasul dengan rela, sangat senang, berbagi hidup mereka, sebab kasih mereka terhadap orang-orang yang baru dimenangkan itu (bdg. I Yoh.

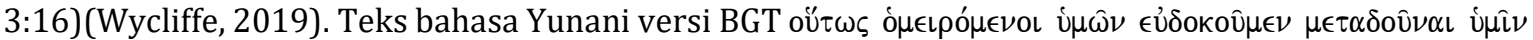

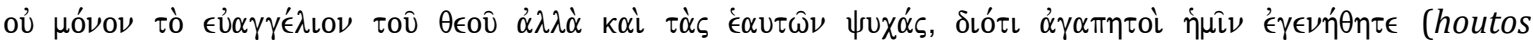
homeiromenoi humon eudokomen metadonai humin ou menon to euanggelion tu teu alla kai tas heauton

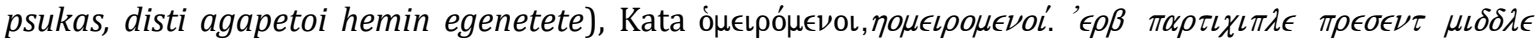

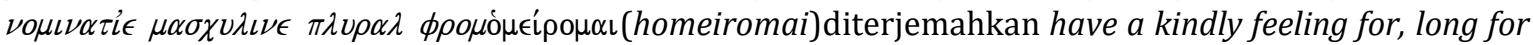
w. gen. (1 Tes. 2:8) (Bibleworks, 2006). Rasul Paulus mengasihi mereka secara pribadi dengan penuh kasih mesra, dan berusaha mendapatkan mereka, bukan milik kepunyaan mereka. Diri merek asendiri, dan bukan harta benda mereka. Untuk meraih mereka, bukan untuk meraih keuntungan melalui mereka, atau untuk menjadikan mereka barang dagangan. Kesejahteraan dan keselamatan rohani dan kekal merekalah yang diainginkan dengan sungguh-sungguh (Henry, 2019).

\section{Keteladanan dalam Perjuangan}

Kehidupan seorang pengajar atau guru penuh perjuangan. Dalam ayat 9 dan 10, terjemahan bahasa Indonesia sehari-hari. Tentu kalian masih ingat bagaimana kerasnya kami berusaha dan berjuang. Siang malam kami bekerja supaya kami tidak menyusahkan seorang pun dari kalian sewaktu kami menyebarkan Kabar Baik yang dari Allah itu kepadamu. Kami hidup dengan suci, benar dan tanpa cela terhadap kalian yang sudah percaya kepada Kristus. Kalianlah saksi-saksi kami, begitu juga Allah. Usaha dan jerih lelah kami Ini adalah istilah bersinonim yang kuat (lih. I Tes. 3:8 dan II Kor. 11:27). Masyarakat Yunani menggunakan istilah usaha / kerjahanya untuk budak. Paulus, sebagai seorang Yahudi, menghormati tenaga kerja manual. Bekerja siang dan malam, menandakan bahwa

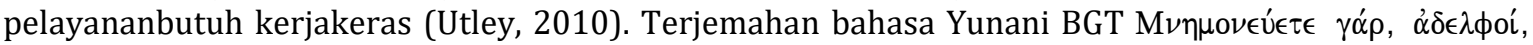

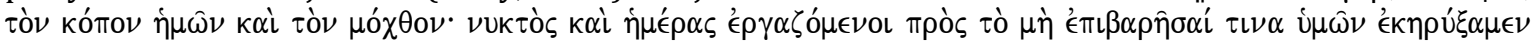

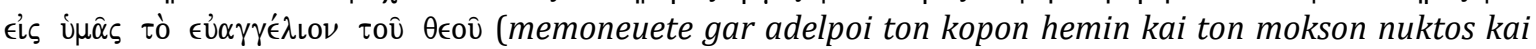
hemas ergaksomeno pros to me epibaresai tina humon ekerussamen eis humas to euanggelion tu teu), .

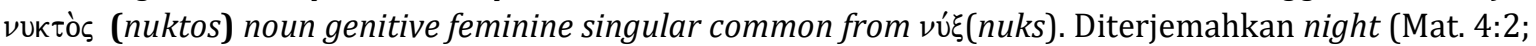
14:25; 28:13; Mrk. 5:5; 14:30; Luk. 5:5; 21:37; Yoh. 13:30; 19:39; Kis. 16:33; 20:31; 23:11; Why. 8:12).

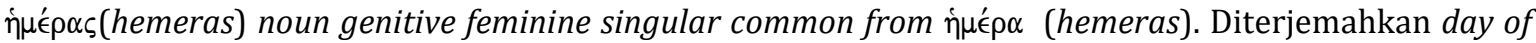
the period of daylight (Mat. 4:2; Mrk. 4:27; Luk. 4:42; 9:12; Yoh. 1:39; 11:9; 2 Ptr. 1:19; Why. 8:12,. 1 Tes. 5:5)(Bibleworks, 2006).Kata usaha digunakan dengan arti yang melelahkan, sedangkan kata jerih lelah dipakai dengan arti sukar(Ellingworth, 2019).

\section{KeteladanandalamKeluarga}

Seorang guru, hendaknya memiliki keteladan dalam keluarga. Ayat 11 dan 12 dalam bahasa Indonesia sehari-hari; kalian tahu bahwa kami memperlakukan kalian masing-masing seperti seorang bapak memperlakukan anak-anaknya. Kami menasihati kalian, kami memberi dorongan kepadamu dan kami mendesak supaya kalian hidup demikian rupa sehingga menyenangkan hati Allah. Karena Allah sudah memanggil kalian untuk menjadi warga Dunia Baru Allah dan menikmati kebesaran-Nya.Dengan suatu kiasan penting yang lain (bdg. 2:7.) Paulus menyamakan dirinya sebagai seorang bapa yang bukan 
Khazanah Theologia, Vol. 2 No. 1: 1-8

Kualifikasi Guru berdasarkan 1 Tesalonika 2:7-12

bertugas untuk mengasuh dan merawat tetapi melatih anak-anaknya. Tiga kata kerja merangkum tugas ini: menasihati (bdg. 2:3), panggilan untuk mengambil tindakan menentukan: menghibur (tidak dicantumkan dalam terjemahan baru Lembaga Alkitab Indonesia; bdg. 5:14; Yoh. 11:19, 31). Paulus dengan lembut memahami keadaan orang-orang yang mengalami kesukaranitu; menguatkan hatimu, mengingatkan merekaakan pentingnya tugas kristiani (bdg. "bersaksi" dalam Ef. 4:17). Nasihat kebapaan ini memiliki satu tujuan: memberikan semangat kepada jemaat di Tesalonika untuk hidup layak di hadapan Allah (bdg. Ef.4:1). Paulus mengibaratkan dirinya sebagai seorang bapak yang menasehati anak-anaknya (Nee \& Lee, 2020). Panggilan Allah secara terus-menerus mendatangi manusia (Wycliffe, 2019). Hidupsesuai, ini adalah sebuah present infinitive. Metafora ini menunjuk pada keberlanjutan gaya hidup manusia, yang harus mencerminkan Guru Agung (lih. Kol. 1:10; 2:6; Ef. 2:10; $4: 1,17 ; 5: 2,15)$. Perhatikan bahwa di akhirya duabelas orang percaya dipanggil untuk berbagi dan dengan demikian mencerminkan kemuliaan Allah(Utley, 2010).

\section{Implikasi}

Ada tiga aspek penting dalam kompetensi abad 21 ini, yaitu: pertama, karakter. Karakter yang dimaksud dalam kompetensi abad 21 terdiri dari karakter yang bersifat akhlak (jujur, amanah, sopansantun) dan karakter kinerja (kerjakeras, tanggungjawab, disiplin, dan gigih). Dalam jiwa dan keseharian seorang guru masa kini sangat penting tertanam karakter akhlak. Dengan karakter akhlak ini seorang guru akan menjadi model bagi semua peserta didiknya. Pembelajaran dengan keteladan dari seorang guru akan lebih bermakna untuk para peserta didik. Kedua, keterampilan. Keterampilan yang perludimiliki oleh guru masa kini untuk menghadapi peserta didik abad 21 antara lain kritis, kreatif, kolaboratif dan komunikatif. Ketiga, literasi. Kompetensi abad 21 mengharuskan guru melek dalam berbagai bidang. Setidaknya mampu menguasai literasi dasar seperti literasi finansial, literasi digital, literasi sains, literasi kewarnegaraan dan kebudayaan. Kemampuan literasi dasar ini menjadi modal bagi para guru masa kini untuk menghadirkan pembelajaran yang lebih variatif, tidak monoton hanya bertumpu pada satu metode pembelajaran yang bias saja membuat para peserta didik tidak berkembang (Latip, 2018). Guru juga harus belajar dari lingkungan. Lingkungan menjadi factor eksternal yang membentuk profesionalitas guru. Sebab, di lingkungan masyarakat, guru menjadi figur yang dicontoh. Dari merekalah penilaian baik buruknya seorang guru didapatkan(Rohman, 2016).

Penelitian DewiHasanah, Rodia Syamwil dan I Made Sudana menemukan bahwa guru yang memiliki sertifikat profesi dan sertifikat kompentensi (SPSK) memiliki kinerja lebih baik dibandingkan guru yang hanya memiliki sertifikat kompentensi (SK) atau sertifika tprofesi (SP) saja. Guru yang hanya memiliki sertifikat profesi mempunyai kinerja yang lebihbaik dibandingkan dengan guru yang memiliki sertifikat kompentensi saja. Guru yang memiliki sertifikat profesi (SP) memiliki kinerja dalam kompentensi pedagogik lebih baik dibandingkan guru yang memiliki sertifikat profesi dan sertifikat kompentensi (SPSK) dan guru yang hanya memiliki sertifikat kompentensi (SK) saja (Hasanah, 2017). Peningkatan kualitas sumberdaya manusia (SDM) khususnya guru dan tenaga kependidikan lainya merupakan suatu condition sine quanon, syarat mutlak bagi kemajuan dunia pendidikan, dan tidak bolehditawar lagi, karena SDM yang berkualitas tidak dapat diwujudkan tanpa adanya proses pendidikan yang berkualitas, dan proses pendidikan yang berkualitas tidak dapat terwujudkan tanpa guru yang berkualitas (professional dan kompeten)(Sunhaji, 2014). Oleh karena itu dalam konteks pendidikan keberadaan pesertadidik memerlukan sosokseorang guru yang bukan sekedar guru tetapi guru yang memiliki kemampuan, kompetensi yang mumpuni dan berkualitas di bidangnya dan senantiasa membimbing, dan mendidik, serta memberikan motivasi kepada peserta didik dalam menjalani kehidupan(Sidik, 2016).

\section{SIMPULAN}

Perkembangan pendidikan khususnya era digital sangat cepat. Sehingga kualifikasi guru menjadi suatu keniscayaan. Guru diperhadapkan dengan sistim pendidikan yang selalu berubah. Perkembangan industri 4.0, bahkan sedang menuju 5.0. Jika dahulu guru diperbolehkan sekolah menengah atas atau sederajat. Namun sekarang, bukan hanya pendidikan akademik saja, karakter yang telah penulis paparkan di atas dapat menjadi contoh atau model kualifikasi guru menuju industri 5.0. 
Keteladanan Paulus pengajar menegaskan bahwa tidak ada alasan apa pun untuk tidak bekerja keras dalam proses pembelajaran. Hal ini Nampak dalam penjelasan sebelumnya bahwa guru sekarang harus kreatif dan dinamis dalam memanfaatkan berbagai sumber dan menggunakan strategi mengajar melaui perkembangan teknologi yang tidak terjebak pada sistem administrasi yang kaku. Tulisan ini dapat menjadi sebagai kontribusibagi guru untuk kemajuan pendidikan. Kajian ini ingin member sumbangan analisis bukan lagi dalam keteladanan Paulus secara biografis seorang tokoh, tetapi sumbangannya dalam hal aktifitas seorang tokoh yang mampu mengubah tantanan sosial di zamannya dan hari ini. Dengan demikian, penelitian mengenai kualifikasi guru berdasarkan 1 Tesalonika 2:7-12 memberi sumbangan konseptual yakni aktivitas guru dalam hal pengajaran yang tidak lagi bersifat elitis dan strukturalis.

\section{REFERENSI}

Arifa, F. N., \& Prayitno, U. S. (2019). Peningkatan Kualitas Pendidikan: Program Pendidikan Profesi Guru Prajabatan dalam Pemenuhan Kebutuhan Guru Profesional di Indonesia. Jurnal Aspirasi, 10(1), 117. https://doi.org/10.22212/aspirasi.v10i1.1229

Bergant, D. ; R. J. K. ed. (2015). Tafsiran Alkitab Perjanjian Baru: 1 Tesalonika. Kanisius.

Bibleworks. (2006). 1 Tesalonika 2:7-12 (7.o.o2g).

Ellingworth, P. E. A. N. P. G. K. (2019). Pedoman Penafsiran Alkitab: Surat-Surat Paulus Kepada Jemaat di Tesalonika. Lembaga Alkitab Indonesia.

Fauzi, I. (2019). Problematika kebijakan linierisasi dan mutasi guru di Kabupaten Jember. Tarbiyatuna: Jurnal Pendidikan Islam, 39-58. https://doi.org/https://doi.org/10.36835/tarbiyatuna.v12i1.351

Hasanah, D.; R. S. I. M. S. (2017). Dampak Sertifikasi Profesi dan Sertifikasi Kompetensi Akuntansiterhadap Kinerja Guru Akuntansi SMK. Journal of Vocational and Career Education, 2(1), 37-42. https://doi.org/https://doi.org/10.15294/jvce.v2i1.10981

Henry, M. (2019). 1 Tesalonika 2:7-12. Sabda.

Jahidi, J. (2017). Kualifikasi dan Kompetensi Guru. Administrasi Pendidikan: Jurnal Ilmiah Mahasiswa Pascasarjana, 2(1), 23-30.

Latip, A. (2018). 4 Kompetensi Guru di Era Revolusi Industri 4.0. Kompasiana. https://www.kompasiana.com/altip/5bfcab25aeebe161c772f98f/4-kompetensi-guru-di-erarevolusi-industri-4-0

Masoka, M., Ibrohim, I., \& Indriwati, S. E. (2017). Studi Eksplorasi Kualifikasi dan Kompetensi Guru Bidang Studi Biologi SMP_SMA sebagai Basis Program Peningkatan Kualitas Pendidikan. Jurnal Pendidikan: Teori, Penelitian, Dan Pengembangan, 2(4), 516-523.

Maura, A. (2018). Fakta Kualitas Guru di Indonesia yang Perlu Anda Ketahui. Ruang Guru. https://blog.ruangguru.com/fakta-kualitas-guru-di-indonesia-yang-perlu-anda-ketahui

Mukti, S. (2017). Pengaruh Kualifikasi Pendidikan dan Pengembangan Karir Terhadap Produktivitas Kerja Guru. Studia Didaktika: Jurnal Bidang Pendidikan, 11(1), 81-90.

Nee, W., \& Lee, W. (2020). Membina Generasi Penerus bagi Hidup Gereja (2). Yayasan Perpustakaan Injil Indonesia.

Pasaribu, M. (2005). Eksposisi Injil Sinoptik: Mengenal Yesus yang diberitakan dalam Injil Matius, Lukas. Gandum Mas.

Putri, M. R. D. (2019). Pemerintah: Jabatan Guru Harus Memiliki Kualifikasi Akademik. Antara News. https://www.antaranews.com/berita/802782/pemerintah-jabatan-guru-harus-milikikualifikasi-akademik

Rohman, M. (2016). Problematika Guru dan Dosen dalam Sistem Pendidikan Nasional. Cendekia, 14(1), 51-71.

Rumahlatu, J. (2019). Keteladanan Kepemimpinan Paulus dalam Surat Tesalonika. Jurnal Pembaharu, $5(1), 1-25$.

Sabda. (2019). 1 Tesalonika 2:7-12. Sabda.

Salamah, U. (2019). Peningkatan Kualitas Pendidikan Melalui Kualifikasi dan Kompetensi Akademik. 
Khazanah Theologia, Vol. 2 No. 1: 1-8

Kualifikasi Guru berdasarkan 1 Tesalonika 2:7-12 Ezra Tari

Evaluasi: Jurnal Manajemen Pendidikan Islam, 3(1), 61-73. https://doi.org/10.32478/evaluasi.v3i1.230

Sidik, F. (2016). Guru Berkualitas Untuk Sumber Daya Manusia Berkualitas. Tadbir: Jurnal Manajemen Pendidikan Islam, 4(2), 109-114.

Sugiyono. (2013). Metode Penelitian Kuantitatif, Kualitatif dan R \& D. Alfabeta.

Sunhaji. (2014). Kualitas Sumber Daya Manusia (Kualifikasi, Kompetensi dan Sertifikasi Guru). Jurnal Kependidikan, 2(1), 142-160. https://doi.org/https://doi.org/10.24090/jk.v2i1.546

Umasuhi, M. M. S. (2014). Analisis Permendiknas Nomor 16 Tahun 2007 dalam angka Menjamin Standarisasi Kualifikasi Akademik dan Kompetensi Guru di Kabupaten Kepulauan Sula. Reformasi: Jurnal Ilmiah Ilmu Sosial Dan Ilmu Politik, 4(1), 16-22. https://doi.org/http://dx.doi.org/10.33366/rfr.v4i1.45

Utley, B. (2010). Galatia dan 1 dan 2 Tesalonika. Bible Lesson International.

Wycliffe. (2019). 1 Tesalonika 2:7-12. Sabda.

Yunus, S. (2017). Mengkritisi Kompetensi Guru. DetikNews. https://news.detik.com/kolom/d3741162/mengkritisi-kompetensi-guru

Yusuf, L. M. (2019). Makna Dialog Yesus dengan Filipus dalam Yohanes 14: 8-14. Visio Dei: Jurnal Teologi Kristen, 1(2), 239-258. https://doi.org/10.35909/visiodei.v1i2.39 